démêler. Je ne cite qu'un exemple, qui sans doute ne sera pas le plus fécond, mais qui mériterait qu'on l'examine : les remarques initiales sur la diversité des façons de parler (78-9) pourraient bien opposer des couples de vertus, pour peu qu'on infléchisse légèrement la traduction ; elles proviendraient alors du De voluptate de Lorenzo Valla, contre lequel Pontano dispute sans vouloir disputer. Le vers d'Horace ensuite cité (oderunt hilarem ...), déjà présent chez Valla, tendrait à confirmer cette hypothèse. Le paradoxe est que le De voluptate, dialogue de teneur épicurienne, critique la morale d'Aristote. Et le chapitre dont paraît s'inspirer Pontano (III, 4) réfute l'existence de ce juste milieu qui lui est si cher.

Mais le simple curieux trouvera lui aussi son compte dans cette lecture. Cicéron n'a certes pas tort de noter que le rire passe mal les frontières et les siècles : certaines des facéties que cite ou qu' invente Pontano, à la suite du Pogge, ne nous amusent plus guère. Et tel n'est pas toujours leur but que de faire rire, comme l'auteur le souligne lui-même. Mais quelques plaisanteries ou mots d'esprit valent largement ces pointes émoussées. On appréciera que cette chose énorme dont Plaute nous dit qu'elle n'est pas une épée ni un concombre finisse in ore matronae, dans la bouche d'une matrone (180). On saura comment faire remarquer à son hôte que le plat n'est pas cuit $(245): \ll$ ah, mais nous étions peut-être invités pour le dîner, pas pour le déjeûner ? » Et l'on retiendra, pour finir, les deux conditions qui permettent à un mariage de durer (197) : que l'homme soit sourd, la femme aveugle.

TRISTAN VIGLIANO, McGill University

\title{
Janet Adelman
}

\section{Blood Relations: Christian and Jew in the Merchant of Venice}

Chicago: University of Chicago Press, 2008. Pp. xi, 226.

Janet Adelman's book Blood Relations: Christian and Jew in the Merchant of Venice presents a thoughtful rereading of Shakespeare's controversial play. Adelman sets out to avoid either transforming Shakespeare into a Jew or adopting a Christian reading of the play; instead, she approaches the theology of the play by re-envisioning the place of the Jew as "not the stranger outside Christianity, but the original stranger within it" (4).

In her introduction Adelman takes issue with scholars' marginalization of the small converted Jewish community in London following the expulsion. She reflects on the experience of these converso Jews, piecing together evidence from court documents and letters to suggest that the converso represents not only the fear that 
some part of the Jew remains in the converted Christian but, moreover, the fear of the other within the Christian himself. Adelman considers an analogue, Sir Thomas More, and a possible source, The Three Ladies of London, for Shakespeare's Merchant to suggest that the depiction of the stranger as simultaneously sympathetic and treacherous, foreign and native has implications for Shakespeare's rewriting of the Christian and the Jew within his play. She also looks at Foxe's A Sermon Preached at the Christening of a Certain Jew to point out the inconsistencies and anxieties inherent in the English drive to construe the Jew as other. Her remaining three chapters explore how the relationship between Christian and Jew is represented in terms of blood: the Christian concern with the blood of Jewish forefathers, Jessica's struggle to escape her own Jewish bloodline, and Shylock and Portia's preoccupation with Christian blood.

Chapter Two focuses on the scene in which Lancelot leaves the house of Shylock, the Jew, to take a position with the Christian Bassanio. Adelman argues that firstly, conversion from Jew to Christian is represented as the deception and rejection of a father by a son; this deception and rejection is played out in Lancelot's conversation with his father and suggests the son's guilt about leaving his father and, consequently, the Christians' uncertainty about their own lineage and guilt at claiming the Jews' promised blessings. Secondly, conversion is depicted as the dispossession of an older brother by a younger one, as evidenced by references to the stories of Jacob and Esau, Ephraim and Manasseh, and the Prodigal Son; while the stories signify the Christian right to the Jewish birthright, they suggest the problems and guilt inherent in the younger (Christian) brother taking the inheritance that rightfully belongs to the elder (Jewish) one. Adelman concludes the chapter with the interesting idea that perhaps the Christian cannot escape the Jew's house, or his Jewish paternity, after all: Lancelot's directions would seem to suggest that every turn - with an etymological play on the root vertere of "conversion" - will lead back to the Jew's house.

Chapter Three explores how Jessica enacts a conversion both similar to and different from Lancelot's. Adelman maintains that conversion, race, and nation come together in the figure of Jessica as she tries, unsuccessfully, to escape her father's bloodline. For Jessica, marriage and conversion have the potential to rid her of her father's Jewish blood, but this proves impossible; as the play takes pains to point out, Jessica cannot be reborn - cannot have a new father. The marker of Jessica's internal difference, her blood, is also re-inscribed externally through the language of race. The word Jew doubles as a religious and racial category in the early modern period; in this sense Jessica's conversion fails to make her Christian, or gentile, and 
this explains why she remains on the margins of the play's Christian Belmont. The play seems to resist Jessica's assimilation into Christianity with continuous reminders that she cannot escape her Jewish birth, while it imagines a difference in skin colour that would distinguish between Jew and Christian and suggests an anxiety about the taint of the Jewish race being perpetuated through the mother. Jessica is also connected to an emerging discourse of nationhood. Jessica's reference to her father's countrymen in effect ties her to the Jewish line through Shem. While old or Jewish notions of nation were based on kin and blood, the new English concept of nation was shifting to refer to those residing within a particular land. The Christian Belmont represents the ideal nation-state where bloodlines are preserved through marriage. Jessica's presence there hints at the problem of a geographical concept of nationhood which would threaten to collapse the difference between the foreign and the native, the Jew and the Christian.

Chapter Four turns to the play's definitive type of the Christian, or Christ, as represented in Antonio. Adelman introduces the idea that Jessica's escape from her father's house disguised as a boy signifies the need to make her part of the circumcised race; Shylock would align Antonio with the Jews through a figurative circumcision, but Portia succeeds in marking Antonio's body as a site of Christian difference. Shylock's would-be incision in Antonio reveals anxieties about inwardness and a Jewish interior that could be shared by Jew and Christian alike. In this sense Antonio's desire to allow Bassanio access to his body or to witness the enactment of his bond suggests the possibility of transgressive desire or the Jew within. Shylock is marked as "other" as he is equated with the Inquisitor or with the Jew who would kill Christ afresh, even as he threatens to undo that difference by exposing that the blood of Christians as indistinguishable from that of Jews. Portia, then, plays a crucial role by preventing the spilling of Christian blood. Here Adelman returns to the slipperiness of gender; when Portia disguises herself as a man, she transfers the feminization of Christ (so troubling to the Christians) to Shylock by stripping him simultaneously of his revenge, his possessions, and his faith; in this act she symbolically castrates and feminizes him.

Adelman's book is a fascinating and thorough look at Judaism and Christianity in Shakespeare's Merchant. It is important for the way it questions our assumptions about Judaism and Christianity within the play and for its ambitious rereading of religion within the play alongside religious and historical texts. The book raises a number of interesting questions. To what extent is the Christian guilt which Adelman locates an early modern response and in what ways is it perhaps a modern construct? Does the rich textual context that Adelman draws on in her first 
two chapters have a bearing on her discussion of gender and religion in her final chapter? Does Shylock's conversion from Jew to Christian also threaten to undo the gendered difference Adelman tries to establish by immediately assimilating the now feminized Jew? Perhaps Adelman answers this final question earlier in the book when she notes Shylock's absence following his enforced conversion, but it seems to have particular relevance to her discussion here. Though she doesn't seem to be aware of it, her study relates in interesting ways to Jonathan Gil Harris's book Foreign Bodies and the Body Politic: Discourses of Social Pathology in Early Modern England (Cambridge: Cambridge University Press, 1998) in which he discusses the Jew as one foreign body and uses a central motif of contagion to describe the English fear of being invaded by foreign others when the real threat or sickness is the other within England itself. The fact that Adelman's study raises such questions is a testament, I think, to its careful scholarship and thought-provoking readings. All in all, Adelman's latest book is a fine achievement.

STACEY KATE PRATT, University of Alberta

\section{Jennifer Summit}

\section{Memory's Library: Medieval Books in Early Modern England}

Chicago and London: University of Chicago Press, 2008. Pp. x, 343.

Habent sua fata libelli. Books do indeed have their fates, and we sometimes forget that in the interim between original use and preservation in a modern repository (if it makes it that far) a book has a long history of use, and often of misuse and abuse. These interim fates are brought to the fore in Jennifer Summit's book, Memory's Library, which takes its title from Book II of The Faerie Queene. Summit focuses her discussion on a few late medieval and early modern libraries and their selective creation of the medieval past. After the dissolution of the monasteries in the $1530 \mathrm{OS}$ and the spoliation of their libraries, Reformation England had to come to terms with its Catholic past and create an English Protestant past out of it. It is this paradox of history with which Summit's book is largely concerned: "the English Middle Ages that we now study is the product of these Renaissance libraries," where manuscripts were chosen, organized, and discarded depending on the collector's intentions for his library. As Summit constructs her argument, the early modern library was not 